\title{
The Effect of Supplementary Materials on Reading Comprehension Improvement of Iranian Female High School EFL Learners Based on Gaj and Khate Sefid Text books
}

\author{
Zahra Abbasi \\ Department of English Language Teaching, Islamic Azad University, Ilam Branch, Ilam, Iran \\ Akbar Azizifar (Corresponding author) \\ Department of English Language Teaching, Islamic Azad University, Ilam Branch, Ilam, Iran \\ E-mail: akb1354@yahoo.com \\ Habib Gowhary \\ Department of English Language Teaching, Islamic Azad University, Ilam Branch, Ilam, Iran \\ Mina Heidari \\ Department of English Language Teaching, Islamic Azad University, Ilam Branch, Ilam, Iran
}

Doi:10.7575/aiac.alls.v.6n.4p.179

URL: http://dx.doi.org/10.7575/aiac.alls.v.6n.4p.179
Received: 10/04/2015

Accepted: 15/06/2015

\begin{abstract}
The Impact of using Supplementary books alongside the national academic text book has received great attention of the curriculum and material developers. Since the beginning of language studies, Second \&Foreign Language Acquisition (SLA \& FLA) researchers have been searching for effective ways of improving learners' language skills. This study aimed at investigating the effects of using supplementary text books (Gaj and Khate Sefid) on English as a foreign language (EFL) learners' Reading skill. Data from this study demonstrate a significant role of using two kinds of books Gaj and Khate Sefid in improving the reading skill of participants in the experimental groups. The findings of this study may help the learners to enhance their independent English language learning and improve their reading comprehension and the overall learning of English by using Supplementary books.
\end{abstract}

Keywords: Reading Comprehension, Supplementary Text books, EFL Learners

\section{Introduction}

The use of supplementary texts like Gaj and Khate Sefid has many benefits for EFL teachers and students in improving vocabulary. By using its passages we can develop vocabulary of EFL learners, EFL teachers have the benefit of teaching vocabulary through context. Teaching vocabulary through context simply means to look for clues in the sentence that might tell the reader something about the meaning of the word in question. Researchers have studied the impact of visual and verbal clues on learning words in context. In this regard, Walters (2006) reported that improved reading comprehension resulted when 11 ESL students, ranging in age from 17 to 47, enrolled in an English language program were shown strategies of how to derive meanings of unfamiliar words from context clues.

Among many strategies for improving reading skill using supplementary books might be one of the effective strategies. Everyone knows about the many text books available in the market. As Richards (2001) holds, for learners the text book might provide the main source of contact they maintain with the language. The way to select the most appropriate one is what needs close scrutiny and research. Taking heed of all these disfavors, in the middle of the 1980s some practitioners and language scholars resurrected literature and related text book as a language learning material after a long period of being neglected (Duff \& Maley, 1991). This can be confirmed by seeing so many publications heralding the coming back of literature (Maley, 1989b) in language classes (e.g. Collie \& Slater, 1987; Duff \& Maley, 1991; Hill, 1986; Maley \& Duff, 1989; McRae, 1991). Besides, applied linguistics fueled the return of literature and supplementary text books for language teaching (Belcher \& Hirvela, 2000).

Supplementary textbooks are considered as a promising tool for language learning purposes. Scholars in the field have proposed various advantages for the use of these books in English as a second or foreign language (ESL/EFL) classes. Stern believes that, supplementary books offer potential benefits of a high order for ESL/EFL. Linguistically, they can help students master the vocabulary and grammar of the language as well as activate the four language skills: reading, writing, listening, and speaking (Celce-Murcia, 1991).

According to Sivasubramaniam (2006), those of us who learned a foreign language through an exposure to its literature will always be intended to speak and read in support of its superiority and efficacy in foreign language teaching. This is to clarify that we have a deeper realization of literature's positive impact on our emotional and mental features. What is 
clear in all language teaching methods and approaches, the materials and text books have always demonstrated the principles and notions prevailing in a given period in history. Supplementary text books deal with things which are interesting in nature and includes little if any uninteresting things (Maley, 1989a).

Literature and language learning promotes cultural and intercultural awareness (Van, 2009) especially in the era of globalization (Tayebipour, 2009) Moreover, due to its authenticity, literature and supplementary texts of different type (here Khate Sefid) can develop sociolinguistic and pragmatic knowledge as manifested in communicative competence models (McKay, 2001).

In Iran, In the realm of textbook evaluation, different authors and researchers have conducted a vast body of studies in different contexts. In this regard, they have used different text books evaluation schemes or checklists. Jahangard (2007) tried to evaluate four EFL text books used in Iranian public highschools and employed a 13 item checklist to investigate the merits and demerits of the textbook. Riazi and Mosallanejad (2010) using Bloom's taxonomy, evaluated the types of learning objectives represented in Iranian senior highschool and pre university English text books. Sahragard, Rahimi and Zare moayeddi (2008) concluded an in depth evaluation of Interchange series with a focus on the real application of communicative and task-based approaches applied in the materials of the text book.

When the learners read out other sources of English and enjoy the success of handling those texts, for sure, it would lead to better understanding of the nature of language and the real successful performance on it. For this reason, students can feel a real sense of achievement at understanding a piece of highly respected text. Also, in the supplementary text books they are really endowed with a lot of points and themes which in close harmony with the real texts of the schools. But the themes should be "consistent with the traditions that the learners are familiar with" (Widdowson, 1983, p. 32) to avoid conflicts and their attentions do not get shattered too much beyond the limits of the expected materials.

It is worth mentioning that supplementary can be used to improve many sub-skills in reading. Learners must be persuaded to predict what is going to occur by reading the title, the first paragraph and to induce what the passage will be about. Then, learners should be able to defend their imaginations with proofs from the text (Goodman, 2007) and the possible impact it may have on the reading performance of the passages. What we see at the end of Gaj and khate sefid series regarding the passages and the short stories for the sake of improving reading ability are all on the line of the same purpose and objective.

Furthermore, as mentioned regarding reading passages, reading short passages can be an input to practice other language skills. Anderson (1967) stated that learners practice the listening skills at the same time when they listen to their classmates retell the stories. After finishing reading, learners can be asked to narrate the story in their own words, to give chronological sequences of happenings in the story, to paraphrase or to state a summary of the story. Besides, students can do the role play, act out some of the story parts, or dramatize the characters in the story. This is due to the fact that they (the skills) interrelated in action.

To sum up, using supplementary textbooks in the classroom can result in better language comprehension and higher interest. This technique can promote learning of cultural aspects and develop learners' motivation. There is little research on this topic, so the present study investigated the effect of the supplementary textbooks on improving learners' reading skills and enhancing their motivation in learning language.

\subsection{Research Question}

Q1: Is there any significant relationship between Gaj and Khate Sefid supplementary text books on Iranian EFL learners' reading performance?

\subsection{Research Hypothesis}

HO1: There is no significant difference between Gaj and Khate Sefid supplementary text books on Iranian EFL learners' reading performance.

\section{Methodology}

\subsection{Participants}

The subjects in this research are 90 Iranian second grade female in highschool female learners studying at Fatemeh Zahra highschool in Ayvan, Ilam, Iran. The number of female learners is equal in three groups.

Among the 150 learners taking the Michigan test, 90 students (the sample of the study) qualified to be classified equally into one control and two experimental groups, each group 30 female members.

\subsection{Instruments}

As the first instrument, a modified Michigan test(version1997), was used to select 90female students at the same level of proficiency among 150second grade learners of English language. Its validity and reliability were taken for granted as they were standardized.

The materials used in this research are selected reading texts of Gaj and Khate Sefid supplementary text books which can be used as tools for applying teaching and reading comprehension in the treatment group's class. Since the participants of experimental group in this research were not familiar with using such books as supplementary text books, the researcher showed them the correct deployment of these texts to the students. The control group's members was conducted in traditional techniques of class using their course national book. 


\subsection{Procedure}

Collecting data started at Mehr1393(Septamber, 2014), the researcher obtained the consent of manager of Fatemeh Zahra highschool located in Ayvan, Iran for participating their second grade learners in the study. In this study, for collecting data, the teacher used Gaj in one of the experimental classes, Khate Sefid in another class (both were focusing on and were specifically developed on these groups of students' grade) along with the normal textbook, as for the control group he just dealt with the normal academic book. At the end of the treatment after two and a half month of Azar(middle of November) the researcher assigned a post test on the materials taught to detect the impact of treatment.

\subsection{Statistical procedure}

After collecting data from the performances of control and experimental groups, the researcher analyzed the data of research groups' performances by helping one Statistics teacher and using SPSS (Statistical Package for Social Science) software.

\section{Results}

In this part, the research hypotheses are considered. To consider the effect of using short story on speaking improvement of learners, the independent T-test was used to compare the score of both control and experimental groups. That will be shown in following.

Table 1. T-test Statistics on the Differences between the Experimental one group and Control Group in Pre-test

\begin{tabular}{|c|c|c|c|c|c|c|c|}
\hline \multirow{3}{*}{ Pre-test scores } & Group & $\mathrm{NO}$ & $\mathrm{M}$ & S.D & $\mathrm{T}$ & $\mathrm{df}$ & Sig.(2-tailed) \\
\hline & C.G & 30 & 13.85 & 3.15 & -0.14 & 58 & 0.88 \\
\hline & E.G1 & 30 & 13.96 & 3.03 & & & \\
\hline
\end{tabular}

The T-test analysis showed that the difference in the pretest means between the control group and the experimental group was not statistically significant, because the $\mathrm{P}$ value $(0.88)$, was higher than 0.05 . Therefore, the null hypothesis was confirmed and it was concluded that, before the beginning of the treatment, both control and experimental groups were of the same level at their reading ability.

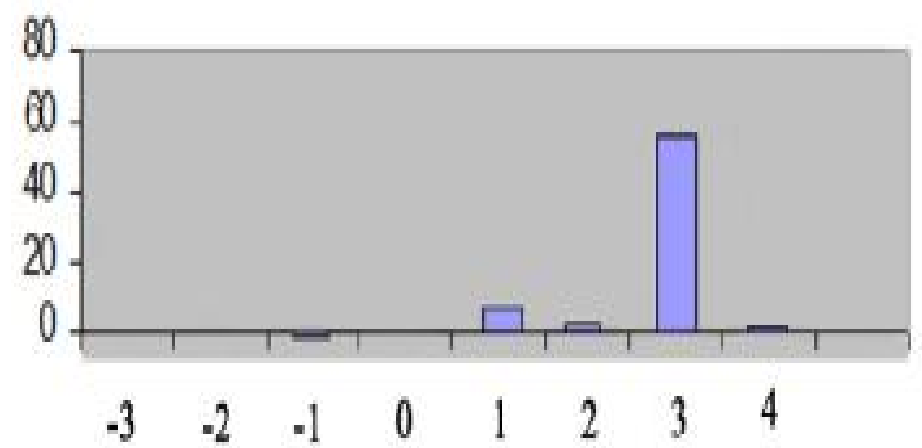

Figure 1. T-test Statistics on the Differences between the Experimental one group and Control Group in Pre-test

The figure for this comparison shows that the experimental group has had a better performance. But the difference is not big enough to be significant.

Table 2. T-test Statistics on the Differences between the Experimental two group and Control Group in Pre-test

\begin{tabular}{lccccccc}
\hline \multirow{3}{*}{ Pre-test scores } & Group & NO & M & S.D & T & df & Sig.(2-tailed) \\
\cline { 2 - 7 } & & & & & & & \\
\cline { 2 - 8 } & C.G & 30 & 13.85 & 3.15 & -0.14 & 58 & 0.86 \\
& E.G2 & 30 & 13.88 & 3.10 & & & \\
\hline
\end{tabular}

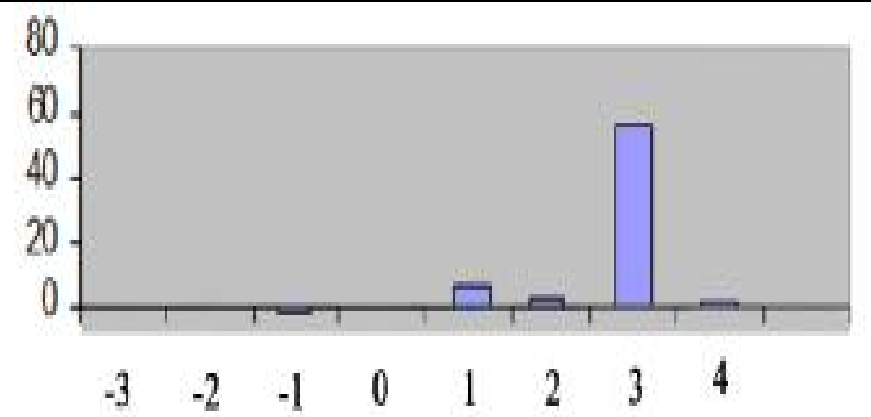

Figure 2. T-test Statistics on the Differences between the Experimental two group and Control Group in Pre-test

Table (2) and its figure shows the better performance of the experimental group in comparison to the control group. The significance of their performance can not be touched upon as they have not yet received the treatment. 
Table 3. T-test Statistics on the Differences between the Experimental one group and Control Group in Post-test

Post-test scores

$\begin{array}{lllllll}\text { Group } & \text { NO } & \text { M } & \text { SD } & \text { T } & \text { df } & \text { Sig.( 2-tailed) }\end{array}$

\begin{tabular}{ccccccc} 
C.G & 30 & 13.93 & 3.56 & -2.09 & 58 & 0.04 \\
E.G1 & 30 & 15.81 & 3.32 & & & \\
\hline
\end{tabular}

The T-test analyses (Table 3) indicated that the difference in the post-test means between the Control group and the Experimental group was statistically significant, because the $\mathrm{P}$ value $(0.04)$ was lower than 0.05 . Therefore, the null hypotheses were rejected. That is, There was a significant difference between the post-test score of the two experimental groups and it was indicated that the students using educational supplementary text books as treatment (experimental groups) performed significantly better than the group having traditional and only national academic text book one (control group). So research hypothesis is confirmed.

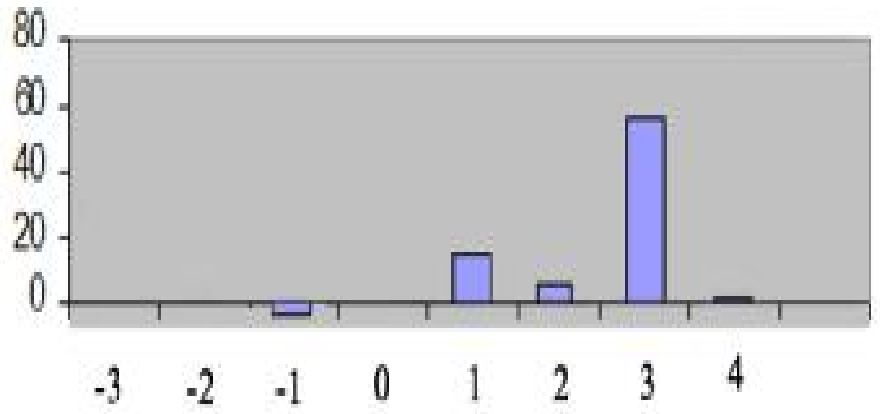

Figure 3. T-test Statistics on the Differences between the Experimental one group and Control Group in Post-test

This figure show the comparison of the post test performance of the experimental one group Khate Sefid, and the control group. As will be seen the difference is significant revealing the acceptal performance of the experimental group and the appropriacy of the treatment.

Table 4. T-test Statistics on the Differences between the Experimental two group and Control Group in Post-test

\begin{tabular}{cccccccc}
\hline Post-test scores & Group & NO & M & S.D & T & df & Sig.(2-tailed) \\
\cline { 2 - 8 } & C.G & 30 & 13.93 & 3.56 & -2.05 & 58 & 0.04 \\
\hline
\end{tabular}

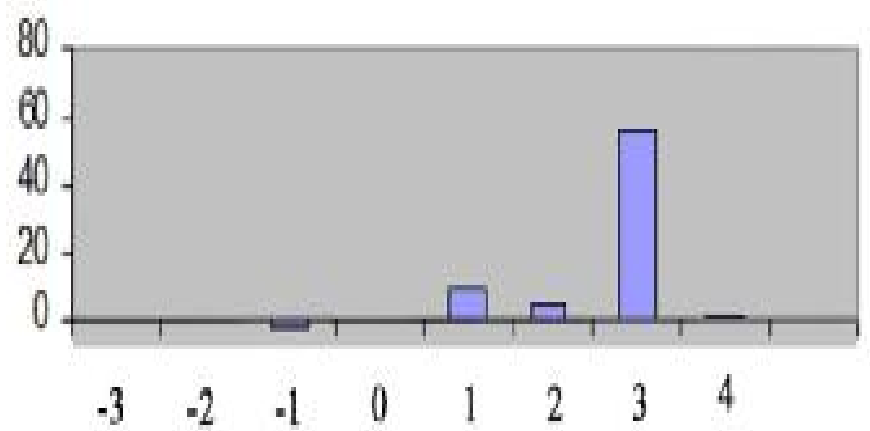

Figure 4. T-test Statistics on the Differences between the Experimental two group and Control Group in Post-test

As seen the difference between their performance is significant revealing the appropriacy of the treatment.

\section{Discussion}

The purpose of this study was to address the effectiveness of using supplementary text books (Gaj and Khate Sefid) on reading skill of learners in classroom.

Findings indicated that using supplementary text books like Gaj and Khate Sefid is effective in improving EFL reading of learners at the intermediate level of English. This result can be more approved by this evidence that there was a significance difference between the means of pre-tests and post-tests. The means of the post-tests were higher than pretests. Also, T-observed were much greater than T-critical. The reason for the better performance of experimental groups in using supplementary might be due to the fact that, using supplementary text books may help them to retain only the main idea of the passages and applying this capability to going over the whole passage and the related questions accordingly. One possible explanation of such result is that positive and correct use of such learning materials by students helps them to enhance their reading proficiency.

Supplementary instructional materials are instructional materials designed to serve, but are not limited to one or more of the following purposes for a given subject or grade level:

1. To provide more complete coverage of a subject or subjects included in a given course. 
2. To provide for meeting the various learning ability levels of students in a given age group or grade level.

3. To provide for meeting the diverse educational needs of students with a language disability in a given age group or grade level.

4. To provide for meeting the diverse educational needs of students reflective of a condition of cultural pluralism.

The students would not feel bored with the environment. This would as well lead to greater concentration on learning materials. Since in this approach teacher is not the sole presenter of materials, students would take an egalitarian attitude towards him/her and so the classroom would be a friendly atmosphere where optimal learning occurs. This positive social atmosphere is assumed to increase learning much more than where learners receive instruction through traditional approaches and focusing just on form and grammar. With regard to this, the teacher puts the burden of learning vocabulary, structure, and class interactions on the learners' shoulders by assigning them some portion of the materials of the supplementary text books.

Deployment of supplementary text books has the potential not only to involve EFL students in an enjoyable reading experience but also to develop their linguistic ability and cultural awareness. They had some doubt in their ability to handle the anticipated difficulty of using short stories, but their attitudes were generally positive. After a semester supplementary text book-using process, they demonstrated improvement not only in attitudes, confidence, and interest, but also in their perceived reading ability.

\section{Conclusion}

As mentioned, this study aimed at testing the research hypothesis including the effect of independent variable (i.e., supplementary text books) on dependent variable (i.e., reading comprehension) of Iranian EFL learners. More specifically, it aimed at understanding the extent to which using supplementary text books would affect reading proficiency among Iranian intermediate students. Also, poor performance of English learners on reading comprehension tests may be due to the negligence of education in the target culture, lack of communicative activities, limited English input outside the classroom, and lack of exposure primarily to other written as opposed to other activities within the classroom, which are the characteristics of foreign language learning settings. After finishing the course of study and by analyzing the data, it was found that using supplementary text books as an instructional tool had a positive impact on reading comprehension of English learners in experimental groups.

This research began with the assumption that teaching supplementary text books materials including Gaj and Khate Sefid could enhance the intermediate language learners' reading capability. Deployment of such supplementary text books promote students' motivation and this makes them more interested in classroom and outside classroom participation while students who merely and conventionally read the main national texts have fewer chance of input and its future intake. Seemingly, it is not easy to stimulate these students to take part in classroom activities since some of them do not have information about such books and they are not interested in more materials for learning Also, many, if not all, students enjoy reading supplementary text books, doing its tests, and learning more about the grammatical and lexical contents of the national routine text books. If strategy training to enhance the reading skill is felt advantageous, it should be used to notifying intermediate language learners of supplementary text books which they have to read outside the classroom to make them better learners and reader of English.

\section{References}

Anderson, V., Dieckman, P., Anderson, S., Ballantine, F., \&Howes, V.M (1967). Reading in the Language Arts.(5th edition). New York: Macmillan.

Belcher, D. \& Hirvela, A. (2000). Literature and L2 composition: Revisiting the debate. Journal of second language writing, 9(1), 21-39.

Celce Murcia, M., D.Brinton and J.Goodwin. (1996). Teaching Pronunciation Cambridge: Cambridge University Press.

Collie, J. and S. Slater (1987): Literature in the Language Classroom. Cambridge: University Press.

Duff, A. \&Maley, A. (1991).Literature. Oxford: Oxford University Press

Goodman, Y. M., \& Carolyn A. B. (1972).Reading Miscue Inventory Manual Procedure For Diagnosis And Evaluation. New York: Macmillan Publishing.

Hill, J. (1986). Using Literature in Language Teaching. London: Macmillan.

Jahangard, (2007). http://www3.telus.net/linguisticsissues/tefliranian.html.

Maley, A. (1989a).Down from the pedestal: Literature as resource. In R. Carter, R. Walker \& C. Brumfit (eds.), Literature and the learner: methodological approaches. (pp. 1-9). Modern English Publications and the British Counsel.

Maley, A. (1989b).A comeback for literature?Practical English Teacher, 10, 59.

Maley, A., \& Duff, A. (1989).The Inward Ear. Cambridge, UK: Cambridge University Press.

McKay, S. (2001) Literature as Content for ESL/EFL. In M. Celce-Murcia (Ed,), Teaching English as a Second or Foreign Language. Heinle\&Heinle.

McRae, J. (1991). Literature with a Small 'l'. London: Macmillan 
Riazi, Mosallanejad (2010). http://www.tesl-ej.org/pdf/ej52/a5.pdf.

Richards, J.C. (2001). Approaches and Methods in Language Teaching. Cambridge: Cambridge University Press.

Sahragard, Rahimi \& Zare moayeddi (2008)

http://www.consortiacademia.org/files/journals/3/articles/70/public/70-268-1-PB.pdf.

Sivasubramaniam, S. (2006).Promoting the Prevalence of Literature in the Practice of Foreign and Second Language Education: Issues and Insights. Retrieved October 9, 2007 from http://asian-efl-journal.com/Dec_06_ss.php

Stern, S. L. (2001) An Integrated Approach to Literature in ESL/EFL. In M. Celce-Murcia (ed.) Teaching English as a Second or Foreign Language.Heinle\&Heinle.

Tayebipour, F. (2009).In Defence of Teaching literature to EFL students in the era of Globalization.

Van, T.T.M. (2009).The relevance of literary analysis to teaching literature in the EFL classroom. English Teaching Forum, 3, 2-9.

Walters, J. (2006). Methods of teaching inferring meaning from context. Regional Language Centre Journal, 37(2), 176-190.

Widdowson, H. G. (1983). Talking shop: H.G. Widdowson on literature and ELT. ELT Journal, 37(1), 30-35. 